\title{
WTO and the Chinese Insurance Industry
}

\author{
J. Tyler Leverty ${ }^{\mathrm{a}}$, Yijia Lin ${ }^{\mathrm{b}}$ and Hao Zhou ${ }^{\mathrm{c}}$ \\ ${ }^{a}$ Department of Finance, Henry B. Tippie College of Business, University of Iowa, 108 John Pappajohn \\ Business Bldg., W286, Iowa City, Ia 52242-19943, U.S.A. \\ E-mail: ty-leverty@uiowa.edu \\ ${ }^{\mathrm{b}}$ University of Nebraska-Lincoln, Lincoln, NE 68588-0490, U.S.A. \\ E-mail: ylin@unlnotes.unl.edu \\ ${ }^{c}$ Allianz General Representative Office, Room C211, Beijing Lufthansa Center, No. 50 Liangmaqiao Road, \\ Beijing 100125, P.R.China. \\ E-mail: hao.zhou@Allianz.com.cn
}

This paper provides new information on the impact of the entry of foreign firms on a financial services industry by examining the Chinese insurance industry surrounding China's accession to the World Trade Organization (WTO). Our analysis reveals that insurers experienced significant growth in total factor productivity over the sample period. We also observe a structural improvement in efficiency after WTO accession, but geographic and product market restrictions placed on foreign firms reduce these positive effects. Overall, the results are consistent with there being a significant increase in social welfare during our sample period, but they also lend support for further deregulation. The Geneva Papers (2009) 34, 440-465. doi:10.1057/gpp.2009.12

Keywords: insurance; efficiency; productivity; WTO

\section{Introduction}

Opening the door to foreign firms is one of the most pervasive economic revolutions sweeping our world in the past 20 years. There are several reasons why reducing restrictions on foreign firms may improve the efficiency and productivity of a domestic financial services industry. ${ }^{1}$ First, managers of domestic firms in markets with high levels of concentration may not have proper incentives to keep costs under control. The presence of foreign competitors, however, may motivate them to cut costs. Second, foreign firms may introduce new services, technology and skills that domestic companies can copy, contributing to more efficient practices. Third, foreign companies may export high skilled managers to work in their foreign branches and/or establish professional training programmes, increasing the quality of human capital in the industry. Finally, the entry of foreign firms may also lead to improvements in regulation and supervision and the development of a legal framework. Overall, greater foreign penetration may increase the efficiency and productivity of the domestic market.

China's accession to the World Trade Organization (WTO) on 11 December 2001 signalled the gradual opening up of a monolithic, domestic oriented and governmentsteered insurance industry to increased foreign competition. This event provides a

\footnotetext{
${ }^{1}$ Cho (1990); Levine (1996); Berger and Hannan (1998); Jayaratne and Strahan (1998); Kroszner (1998).
} 
unique opportunity to investigate the impact of reducing restrictions on foreign firms on a domestic financial services industry. The objective of this study is to seize this opportunity by examining the efficiency of insurers surrounding China's accession to the WTO.

This study is at the intersection of two lines of research: analyses of insurer efficiency and examinations of relaxing foreign entry restrictions in the financial services industry on firm performance. Most of the insurance efficiency studies to date have evaluated the performance of insurers in the U.S. ${ }^{2}$ and other developed countries. ${ }^{3}$ While these studies have improved our understanding of the efficiency of insurers, there is a paucity of research examining insurer performance in developing countries, especially in a developing country as important as China. We are aware of only two studies examining insurer efficiency in China. ${ }^{4,5}$ The vast majority of the studies examining the relaxation of foreign entry restrictions in the financial services industry are focused on the banking sector. ${ }^{6}$ There is a dearth of research analysing the entry of foreign firms in the insurance sector and no research examining the entry of foreign firms in the Chinese insurance industry. Therefore, this paper extends the current literature by investigating the impact of relaxing foreign entry restrictions in a non-banking financial services market and by examining insurer efficiency in a non-Western country.

This paper also contributes to the literature in a number of other dimensions. First, prior research typically overlooks the estimation bias in frontier efficiency created by the small number of firms that characterise developing markets. ${ }^{7}$ To address the bias, we calculate bias-free estimates of efficiency and productivity using a bootstrapping technique. ${ }^{8}$ Neither of the previous studies on the Chinese insurance industry addresses the bias in their efficiency estimates. ${ }^{9}$ We document that the bias is quite severe and the failure to correct for it may lead to misleading conclusions. Second, this paper introduces to the insurance literature an empirical approach to handle the potential serial correlation injected into a second stage regression when calculated efficiencies are used as the dependent variable. To handle the unaccounted variation, we specify the second step explanatory regression as a Stochastic Frontier Analysis (SFA) model $^{10}$ Third, to our knowledge, this paper is the first to apply count model regression techniques to analyse the characteristics of the reference set of

\footnotetext{
${ }^{2}$ See Cummins and Weiss (2001) for a review of this literature.

${ }^{3}$ Cummins et al. (2004); Ennsfellner et al. (2004); Barros et al. (2005); Cummins and Rubio-Misas (2006).

${ }^{4}$ Chen et al. (2007); Yao et al. (2007).

5 The Chen et al. (2007) study examines the frontier efficiency of Chinese life insurers. No hypotheses are tested. Yao et al. (2007) examine the efficiency of Chinese insurers and assess the determinants of efficiency. Neither study addresses the small sample bias inherent in their efficiency estimates nor the potential serial correlation injected into a second stage regression. More importantly, neither paper addresses the impact of the entry of foreign firms on the industry or the impact of WTO.

${ }^{6}$ Cho (1990); Barajas et al. (2000); Claessens et al. (2001); Demirguc-Kunt et al. (2002); Unite and Sullivan (2003); Lensink and Hermes (2004); Bonin et al. (2005); Berger et al. (2008).

7 Simar and Wilson (2000).

${ }^{8}$ Simar and Wilson $(1999,2000)$.

${ }^{9}$ Chen et al. (2007); Yao et al. (2007).

${ }^{10}$ Bhattacharyya et al. (1997).
} 
"best-practice" firms. This methodology allows us to pinpoint which insurers are driving performance in the market.

Our empirical results broadly support the hypothesis that reducing restriction on foreign insurers improves efficiency. From 1999 to 2004, property and casualty (P\&C) and life insurers experienced annual average productivity growth of 19.8 and 15.0 per cent, respectively. There is a significant structural improvement in productivity attributable to WTO accession. In addition, we find direct evidence that non-domestic firms positively influence insurer performance, indicating that domestic insurers benefit from the entrance of foreign insurers who bring additional capital, advanced technology, experienced management and new approaches to distributing insurance products. ${ }^{11} \mathrm{We}$ also discover that restrictions imposed on the geographic and product scope of foreign insurers retard efficiency and productivity.

We conclude that our evidence indicates that the entry of foreign firms in the Chinese insurance market resulted in substantial welfare gains, but that China's restrictions on foreign insurers moderated these gains. The remaining paper proceeds as follows. The first section provides an overview of the Chinese insurance market. The second section describes the empirical methodology. The third section discusses the unique data set and the inputs and outputs used in the efficiency and productivity analyses, the fourth section presents the empirical findings and then the paper concludes.

\section{An overview of the Chinese insurance market}

The Chinese insurance market has changed relatively rapidly over the last decade. To convey all the changes effectively we will discuss the market in two steps. First, we will describe the history of the Chinese insurance market. Second, we will communicate the status of the modern market by reporting the conditions of the market prior to WTO accession, highlighting China's WTO commitments related to insurance and tracing China's progress on these commitments.

\section{History of the Chinese insurance market}

The first insurance institution in China, the Canton Insurance Society, was established by foreign insurers in 1805. Between 1805 and 1948, numerous foreign and domestic insurers entered the Chinese market. With the founding of the People's Republic of China (PRC) in 1949, however, all foreign insurers were required to terminate operations and leave the country. The PRC nationalised all domestic insurers and established a state-monopoly, the People's Insurance Company of China (PICC). In 1979, China's "Reform and Open" policy initiated a series of reforms with the purpose of stimulating economic growth. As a result of these policies, China reinvigorated its insurance industry and the industry developed quickly. From 1980 to 1998, insurance premiums grew at an approximate rate of 40 per cent per year - a rate that far outpaced the country's 9.7 per cent annual GDP growth rate.

\footnotetext{
${ }^{11}$ Shen (2000); Sun (2003); D'Arcy and Xia (2003); Guan (2003); Xu and Li (2003); Wang et al. (2006).
} 
China dissolved the state-owned monopoly in 1988 when it allowed Ping An Insurance Company, a shareholder-owned insurer, to enter the market. The Chinese insurance market changed significantly in 1992, when the People's Bank of China granted American International Group, Inc. (AIG) a licence to sell individual life insurance. ${ }^{12}$ It became the first foreign insurer since 1952 to establish a branch office in China. This act officially marked the opening of the Chinese insurance market to foreign firms. The American International Underwriters (AIU), one of AIG's affiliates, set up the first foreign $\mathrm{P} \& \mathrm{C}$ branch in Shanghai 3 years later. Between 1992 and 1998, 10 joint ventures (JVs) and foreign branches obtained licences to write insurance in China.

In order to protect the nascent Chinese domestic industry, China's regulatory policy was based on a "gradual, paced" approach to permitting foreign competitors into the market. Foreign insurers, as a result, faced numerous entry barriers. The process to obtain a foreign licence lacked transparency and the rules governing the licensing process were applied unevenly. Before 1998, 113 applications for licences from 17 countries were denied. Foreign insurers and JVs were also subject to a number of regulatory restrictions not placed on domestic firms. For example, they were only allowed to operate in Shanghai and Guangzhou. In addition, foreign P\&C insurance companies were only allowed to set up branch offices. As a result of these regulatory restrictions, foreign insurers held less than 1 per cent of the nationwide insurance market in 1998. The premium income of the top four domestic Chinese insurers, on the other hand, accounted for roughly 96 per cent of the total Chinese insurance premiums in 1998.

\section{The modern Chinese insurance market (1999-2004)}

China formally requested accession to the General Agreement on Tariffs and Trade (GATT) on 11 July 1986. After 13 years, Washington and Beijing reached a bilateral agreement on the conditions for China's entry into the WTO on 15 November 1999. The agreement paved the way for China to enter the WTO.

With pressure from the international insurance community and in preparation for accession into the WTO, the China Insurance Regulatory Commission (CIRC) encouraged China's government to issue licences to new domestic and foreign insurers. ${ }^{13}$ In order to obtain a business licence, prospective foreign insurers had to meet a number of formal and informal requirements. ${ }^{14}$ In 2000 alone, the CIRC granted licences to four new JVs and 36 branches of domestic and foreign insurers. The potential for increased competition propelled China's domestic industry to undertake a number of market-oriented reforms to improve their competitive edge. ${ }^{15}$ For example, the state-owned giants, PICC and China Life, rescaled their organisations at the provincial and county levels and streamlined their staff.

\footnotetext{
${ }^{12} \mathrm{Wu}$ and Strange (2000); Wang et al. (2006).

${ }^{13} \mathrm{Ng}$ and Whalley (2004).

${ }^{14}$ Refer to the Appendix for the list of formal and informal requirements for foreign insurers.

15 Guan (2003).
} 
Compared to domestic companies, foreign insurers did not enjoy the same flexibility to make adjustments for China's WTO accession. Except for granting additional licences, China largely imposed the same restrictions on foreign insurance companies as it did prior to 1998 .

Another potential barrier to foreign insurer market share is the complexity of business in China. Wu and Strange ${ }^{16}$ state that foreign insurers see the Chinese market as complex because of China's unusual organisational forms, complicated legal arrangements, different business customs and the need for Chinese language skills to conduct business. Overall, the regulatory restrictions and cultural complications impeded foreign insurers' ability to obtain market share. In 2001, the foreign insurers in our data set only had 0.73 per cent of the Chinese P\&C market and 1.64 per cent of the life insurance market $(0.58$ per cent for $\mathrm{JV}$ firms and 1.16 per cent for foreign insurers).

China became an official member of the WTO on 11 December 2001. China's major WTO commitments related to insurance include measures on: ${ }^{17}$

(1) Geographic restrictions: Immediately after WTO entry, foreign P\&C insurers and JVs will be allowed to offer services in Shanghai, Guangzhou, Dalian, Shenzhen and Foshan. Two years after entry, foreign firms can extend their business to Beijing, Chengdu, Chongqing, Fuzhou, Suzhou, Xiamen, Ningbo, Shenyang, Wuhan and Tianjin. All geographical restrictions will be removed 3 years after entry. Upon accession, $\mathrm{P} \& \mathrm{C}$ insurers from abroad will be permitted to engage in general insurance policies and large-scale commercial insurance without any geographical limitation.

(2) Reinsurance requirements: Gradually phase out the 20 per cent reinsurance requirement over a 4-year period following accession.

(3) Business scope: Upon accession, foreign P\&C insurers will be allowed to offer $\mathrm{P} \& \mathrm{C}$ services to overseas enterprises, property insurance to foreign-funded enterprises in China, and liability and credit insurance within its business territory. In addition, foreign $\mathrm{P} \& \mathrm{C}$ insurers will be permitted to offer $\mathrm{P} \& \mathrm{C}$ insurance service to clients beyond its business territory if the insurance meets the requirements of a Master Policy or a Large Scale Commercial Risk. ${ }^{18}$ Two years after entry, foreign P\&C insurers will be able to offer all $\mathrm{P} \& \mathrm{C}$ insurance products (except third-party motor insurance) to Chinese and foreign customers. Upon accession, foreign life insurance companies may provide individual life insurance services to foreign and Chinese citizens. Three years after entry, they can provide health insurance, group insurance, pension and annuity products.

\footnotetext{
${ }^{16} \mathrm{Wu}$ and Strange (2000).

${ }^{17}$ Sun (2003).

${ }^{18}$ The master policy applies to the following situations: (a) if an enterprise and a foreign P\&C insurer are registered in the same territory, the foreign $\mathrm{P} \& \mathrm{C}$ insurer can issue a master policy to cover the insured enterprise's risks outside the territory; (b) if the premium paid for the insured risk in a particular territory exceeds 50 per cent of an enterprise's total premium, then the foreign insurer can also issue a master policy to cover all of the enterprise's risks in China. The master policy does not apply to automobile, credit, guarantee or nuclear insurance.
} 
(4) Ownership: Two years after entry, P\&C insurers will be allowed to form wholly owned foreign subsidiaries. ${ }^{19}$ Upon accession, foreign life insurers can hold no more than a 50 per cent ownership stake in a JV. Before joining the WTO, China approved three life insurance JVs with 51 per cent foreign ownership (AXAMinmetals, China Life-CMG and Allianz DaZhong Life), so this commitment is actually a step backward. In sum, WTO commitments allow foreign P\&C insurers relatively greater access to the market on a shortened time schedule than foreign life insurers.

In December 2001, following its WTO commitments China began to gradually remove geographic, product, reinsurance, ownership and other restrictions. The process, however, has been completed in a piecemeal fashion. Since some of the restrictions were not removed until 2005, our sample period which ends in 2004 captures a transition phase. The performance of foreign insurers relative to domestic insurers is difficult to project since a number of barriers may impede their ability to compete. First, insurance regulation in China places a number of restrictions on foreign and $\mathrm{JV}$ insurers that are not similarly imposed on domestic insurers. These uneven restrictions may weaken any positive impacts from liberalisation. ${ }^{20}$ Second, it takes time for foreign insurers to familiarise themselves with the Chinese business climate, language and regulations. Together these factors may create an indirect barrier to entry. ${ }^{21}$ Last but not least, cultural differences and a lack of mutual trust and agreement between foreign insurance investors and Chinese employees, managers or partners could impede performance, especially for JVs. ${ }^{22}$

\section{Methodology}

We estimate measures of pure technical, scale and total technical efficiency. Technical efficiency (TE) refers to the ability to avoid waste by producing as much output as input usage allows. Pure technical efficiency (PTE) is the proportion by which the firm could reduce its input usage by adopting the best technology represented by the variable returns to scale (VRS) frontier. A firm operating on the VRS frontier is scale inefficient if it is not operating on the constant returns to scale (CRS) frontier. Scale efficiency (SE) is measured as the ratio from the CRS to the VRS frontier. Scale inefficiency results from firms operating with either decreasing (DRS) or increasing returns to scale (IRS).

\footnotetext{
${ }^{19}$ Before accession, foreign P\&C insurers were only permitted to set up branches. The foreign parent companies were responsible for the liabilities of their branches. In May 2004, the CIRC officially issued a circular for foreign P\&C insurance branches to apply for transformation to subsidiaries. At the end of May 2004, Min An (Hong Kong) Shenzhen Branch received the first approval to transform to a subsidiary. BOC Insurance (Hong Kong) Shenzhen Branch, Samsung Shanghai Branch and Sompo Insurance Dalian Branch also later obtained approval.

${ }^{20}$ Whalley (2003).

${ }^{21}$ Berger et al. (2000b).

${ }^{22}$ Yuan (2002).
} 
We use data envelopment analysis (DEA) to estimate frontier efficiency. ${ }^{23}$ DEA has been widely used to measure efficiency for financial institutions (see Berger and Humphrey (1997) for a review of this literature). DEA is a non-parametric method that compares each firm in the industry to a "best-practice" efficient frontier formed by a convex combination of the most efficient firms in the sample. A firm is fully efficient (efficiency of 1.0) if it lies on this frontier. A firm is inefficient (efficiency $<1.0$ ) if it is not on the frontier, indicating that its outputs could be produced more efficiently by another firm or set of firms.

We adopt DEA for this study for four reasons: (1) it is not necessary to identify a functional form or make distributional assumptions; (2) it is able to handle relatively small sample sizes, which is ideal for analysing the Chinese insurance market; (3) it allows for the convenient decomposition of total technical efficiency (TE) into pure technical efficiency (PTE) and scale efficiency (SE); and (4) the Malmquist technique, which is the standard approach for measuring the evolution of efficiency over time, is DEA-based.

We use the Malmquist index to examine productivity. ${ }^{24,25}$ The Malmquist index is greater than one when there has been total factor productivity (TFP) progress and it is less than one when there has been a decrease in total factor productivity. The Malmquist approach also allows us to part shifts in the frontier, technological change (TC), from improvements in efficiency relative to the frontier, technical efficiency change (TEC). TEC has a value of one when there is no change in technical efficiency. If the firm is closer to the frontier in period $t+1$ than in period $t$, then TEC is greater than 1 . If the firm is further from the frontier in period $t+1$ than in period $t$, then TEC is less than 1 . Similarly, TC has a value of one when technical change has not occurred, and has a value greater or less than one if technical change has been progressive or regressive.

Prior studies have endeavoured to explain the variation in calculated efficiencies using a second step regression, in which efficiency or productivity is regressed on a set of exogenous variables using ordinary least squares (OLS) or Tobit methods. There are two shortcomings of this approach: (1) DEA efficiency (productivity) scores are biased in finite samples; ${ }^{26}$ and (2) the included explanatory variables may fail to explain the entire variation in the calculated efficiencies and this unexplained variation may mix with the white noise error term and contaminate the estimated regression coefficients.

To ameliorate the inherent bias in DEA efficiency (productivity) scores, we bootstrap our estimates. DEA measures efficiency relative to a non-parametric, maximum likelihood estimate of an unobserved true frontier, conditional on observed data resulting from an underlying data-generating process (DGP). ${ }^{27}$ DEA estimates of

\footnotetext{
${ }^{23}$ To keep it short, we do not discuss DEA in detail. A description of DEA is provided in Charnes et al. (1994). The methodology has also been outlined in insurance studies (e.g. Cummins and Weiss, 2001).

${ }^{24}$ Grosskopf (1993).

${ }^{25}$ Additional details on the Malmquist index are available in Charnes et al. (1994).

${ }^{26}$ Simar and Wilson (1998, 1999, 2000).

${ }^{27}$ Although DEA was traditionally viewed as a strictly non-parametric methodology, research has shown that it can be interpreted as a maximum likelihood procedure (e.g. Banker, 1993). As such, DEA is consistent and converges faster than other estimation techniques.
} 
efficiency are calculated based on a sample of firms and some feasible efficient production possibilities that are not observed in the sample are excluded; therefore, empirical estimates of efficiency are upward biased. ${ }^{28}$ Most researchers ignore the upward bias, but ignoring it can lead to potentially misleading conclusions. To correct the efficiency and productivity estimates for bias, we use the bootstrapping techniques of Simar and Wilson. ${ }^{29}$ The bootstrapping procedure uses 2000 replications. We estimate efficiency (productivity) separately for the $\mathrm{P} \& \mathrm{C}$ and life insurance industries and for each year (2-year period) of the sample.

To handle the unaccounted variation, we specify the second step regression as a Stochastic Frontier Model (SFA) rather than as an OLS or Tobit model. ${ }^{30}$ The SFA model allows for the decomposition of the unexplained part of efficiency variation from the white noise error term. The error term, $\varepsilon_{i t}$, in an SFA regression has two components, a normally distributed white noise part $\left(u_{i t}\right)$ and a one-sided part that captures the variation in the efficiency estimates that is not associated with the explanatory variables $\left(v_{i t} \geqslant 0\right)$. The SFA specification allows for the decomposition of the variation in efficiency estimates into a systematic component, which catches the effect of the exogenous variables on efficiency variation, and a random component.

\section{Chinese insurance data, outputs and inputs}

The data used in this study are drawn from the China Insurance Regulatory Commission (1999-2004) (CIRC), which is the sole authoritative source for Chinese insurance data. CIRC Editorial Department began publishing data on an annual basis in 1998. The company edition publishes the financial statements of all domestic, JV and foreign insurers conducting business in China. The CIRC mandates and institutes uniform financial reporting and the data in the yearbook follow these CIRC regulations. ${ }^{31}$ All reported information is checked and approved by the General Affairs Office of the CIRC. All insurers operating in China must follow the Company Law of the People's Republic of China. Article 175 of the Company Law was amended in 1999, requiring all registered companies to prepare their financial and accounting reports at the end of each fiscal year and all financial reports must be reviewed and audited in accordance with the law (see The Chinese Civil Law Forum -

${ }^{28}$ Simar and Wilson (1998).

${ }^{29}$ For the sake of brevity, we refer readers to Simar and Wilson (1999, 2000) for details on DEA bootstrapping. FEAR, a package for frontier efficiency analysis in R, is used to estimate efficiency and productivity and for the bootstrapping procedures (Wilson, 2007).

${ }^{30}$ Bhattacharyya et al. (1997).

31 According to the Insurance Law of the People's Republic of China in 1995 and the Provisional Rules on Administration of Insurance Companies in 1996, an insurer should submit financial statements to the CIRC in accordance with the relevant State laws, administrative regulations and the stipulations of the State financial and accounting systems (i.e. the Chinese GAAP). For example, reserve calculation should follow Article 93 of the Insurance Law of the People's Republic of China. The amount set aside and carried forward for non-life insurers "shall be equal to fifty per cent of the premiums retained for the current year". For life insurers, they "shall set aside a reserve for future claims equal to the total net value determined actuarially on the total life insurance policies in force". 
www.cclaw.net). In order to be certain of the veracity of the data, we begin our analysis in 1999 when the CIRC officially began annual audits. ${ }^{32}$

We treat each accounting reporting entity as a business entity. Since subsidiaries (e.g. AIA Shanghai, AIA Guangzhou) and branches report their own financial statements, they are recognised as distinct entities. As mentioned in the second section, there are two types of firms in the Chinese P\&C insurance market (domestic and foreign insurers) and three types in the life insurance market (domestic, JV and AIG affiliate). In a majority of our regression models we distinguish domestic insurers from non-domestic insurers - defined as foreign $\mathrm{P} \& \mathrm{C}$, AIG affiliated life and JV life insurers. In other regressions, we further categorise non-domestic insurers into foreign (foreign P\&C and AIG Affiliated life insurers) and JV firms.

In accordance with a majority of the recent literature on financial institutions, we adopt a modified version of the value-added approach to identify insurer outputs. ${ }^{33}$ Leverty and Grace ${ }^{34}$ examine other approaches to measuring insurance output and find that the value-added approach is the most consistent with the economic realities of the insurance market. The approach's output measure has three components: (a) risk-pooling and risk-bearing; (b) "real" financial services relating to insured losses and (c) financial intermediation. In defining measures for insurance output, we are searching for proxies for the quantity of insurance services provided.

Since the products offered by life and $P \& C$ insurers differ, different sets of output definitions are used for each sector. Recent research uses incurred benefits plus additions to reserves as proxies for the risk-pooling and risk-bearing functions of life insurers. ${ }^{35}$ Constraints imposed by the data, however, require us to use a premiumbased measure for the risk-bearing and real insurance services output. ${ }^{36}$ Premium income has also been used in past efficiency studies. ${ }^{37}$ Premium income is appropriate as an output measure under the assumption that life insurance is a homogeneous product and that all insurers charge the same price. This assumption is not very restrictive since life insurance is a fairly homogenous product and because the Chinese government strictly regulates insurance prices. ${ }^{38}$ Because the products offered by life insurers differ in their degree of risk-bearing and real insurance services, we categorise life insurance products into three outputs: premiums written in (1) group life and annuities; (2) individual life and annuities; and (3) accident and health insurance.

${ }^{32}$ Other published articles use the yearbook data prior to 1999 so our approach is more conservative (e.g. Shen (2000), Zou and Adams (2006)). To further insure the credibility of the data, we also carefully scrutinise each insurer's data to make sure that the reported variables make sense and are consistent with their other filings.

${ }^{33}$ Berger and Humphrey (1992); Cummins and Weiss (2001).

34 Leverty and Grace (2007).

${ }^{35}$ Yuengert (1993); Berger et al. (2000a).

${ }^{36}$ Although premiums capture the flow of services to policyholders, they also include a component for expenses and profits. In fact, premium income is really a form of revenue (price times quantity), not the quantity of output (Yuengert, 1993). As such, systematic differences in price across insurers may lead to misleading inferences.

${ }^{37}$ See, for example, Gardner and Grace (1993).

${ }^{38}$ Sun (2003). 
For $\mathrm{P} \& \mathrm{C}$ insurers, the most common proxy for the quantity of risk-pooling and real insurance services is losses incurred. ${ }^{39}$ To capture the different types of services provided by the main types of $\mathrm{P} \& \mathrm{C}$ insurance, we use as separate output measures short-tail personal lines losses, long-tail personal lines losses, short-tail commercial lines losses and long-tail commercial lines losses. ${ }^{40}$ Present valuation is typically used to recognise the fact that the payout tails vary among the principal types of insurance; ${ }^{41}$ however, due to the constraints of our database, we are not able to estimate cash flow patterns. Nevertheless, the inability to estimate cash flow patterns is not a serious limitation because the vast majority of insurance in China is of the shorttail variety. ${ }^{42}$

In addition to the risk-bearing and real insurance services, we also account for the intermediation function of both life and $\mathrm{P} \& \mathrm{C}$ insurers. The intermediation function is the act of borrowing from policy-holders and investing the funds in marketable securities. Consistent with recent insurance efficiency studies, ${ }^{43}$ we use total invested assets as our measure of financial intermediation.

Insurer inputs are commonly classified into three broad groups: labour, business services and materials, and capital. ${ }^{44}$ Our database, however, does not allow us to separate labour input from business services and materials. Instead, we capture total business expenses, the sum of underwriting and investment expenses. In accordance with the literature, we classify capital into financial equity capital and debt capital. Debt capital for insurers is mainly comprised of funds borrowed from policy-holders. For life insurers, these funds consist of the aggregate reserve for life policies and contracts, the liability for premium and other deposit funds, and other reserve items. For $\mathrm{P} \& \mathrm{C}$ insurers, debt capital includes the sum of loss reserves and unearned premiums reserves. The quantity of financial equity capital is defined as the sum of capital and policy-holders surplus.

To summarise, we utilise four outputs for life insurers (net premiums written for group, personal, and accident and health insurance, and real invested assets) and five outputs for P\&C insurers (losses incurred for short-tail personal, long-tail personal, short-tail commercial, and long-tail commercial lines and real invested assets). The same three inputs are used for both life and P\&C insurers - business expenses, financial equity capital and debt capital. ${ }^{45}$ We capture all firms for which there is adequate and meaningful data. In order to be included in the final sample, firms must have a minimum of one positive input and one positive line of business output. Firms must also have financial capital and invested assets greater than zero. All data are reported in the local currency - RMB. All variables are expressed in real terms by

\footnotetext{
${ }^{39}$ Cummins and Weiss (2001).

${ }^{40}$ Tail length refers to the length of the loss cash flow stream. Line of business definitions conform as closely as possible to those described in Phillips et al. (1998).

${ }^{41}$ Cummins and Weiss (2001).

${ }^{42}$ Short-tail property-casualty lines made up 97 per cent of the total losses incurred from 1999 to 2004.

${ }^{43}$ Cummins and Weiss (2001).

${ }^{44}$ Berger et al. (2000a); Cummins and Weiss (2001).

${ }^{45}$ Details on the mapping of the Chinese Insurance Yearbook financial statement variables to the input and output measures are available from the authors upon request.
} 
deflating to 1999 using China's Consumer Price Index (CPI). ${ }^{46}$ The final sample represents more than 90 per cent of the total assets in the Chinese insurance industry. It is comprised of $121 \mathrm{P} \& \mathrm{C}$ and 116 life insurer firm-years.

\section{Empirical findings}

\section{Summary statistics}

The number of firms in the sample trends upwards over the sample period. From 1999 to 2004, the number of P\&C insurers increases from 15 to 27 and the number of life insurers climbs from 13 to 29 . The presence of foreign P\&C insurers and JV life insurers rises from 7 to 15 and from 4 to 18 , respectively. Summary statistics are shown in Table 1. On average domestic insurers are much larger than foreign insurers. The average domestic $\mathrm{P} \& \mathrm{C}$ insurer has assets of 3,411 million RMB compared to 155 million RMB for foreign P\&C firms. Domestic insurers also have significantly greater input and output quantities than non-domestic firms. The size difference is even more extreme in the life insurance industry. The summary statistics also reveal some of the restrictions placed on non-domestic insurers. Since third party auto and group life insurance are off limits to non-domestic insurers, these firms have zero losses in $\mathrm{P} \& \mathrm{C}$ personal long-tail lines of business and zero premiums written in group life. The asset-to-liability ratio displays the high capital requirement put on nondomestic insurers.

Table 2 summarises the efficiency results. Only the bias-corrected efficiency estimates are reported. The bias-corrected efficiency scores are consistently lower than the original efficiency scores. The results indicate bias-corrected reductions of as much as 17.5 per cent and 20.3 per cent for the P\&C and life samples, respectively. These large adjustments in efficiency suggest that bias-corrections are important when absolute levels of efficiency are of interest. To determine whether the relative rankings of the original and bias-corrected efficiency scores are similar, we calculate Spearman rank-order correlations. For the P\&C sample, the correlation ranges from 62.9 to 91.2 per cent. The range for the life sample is 7.9 to 96.3 per cent. The low correlation in the life sample suggests that the original estimates may not produce similar conclusions as the bias-corrected estimates. Our correlations are much lower than those reported in studies of the U.S. insurance market, ${ }^{47}$ documenting the import of bias-correction in studies of the Chinese insurance market since it is characterised by a small number of insurers. To avoid making misleading conclusions, the remainder of the analysis relies upon the bias-corrected efficiency estimates.

Average technical efficiency (TE) in the P\&C market is 0.732 over the sample period. It is 0.685 in 1999 and increases to 0.718 in 2004 (the year-by-year results are not tabulated to conserve space). The main source of technical inefficiency is pure technical inefficiency. Average pure technical efficiency (PTE) is 0.782 , indicating that

\footnotetext{
${ }^{46}$ The CPI data come from the "Annual Statistics Communique of National Economy and Social Development", National Bureau of Statistics of China, http://www.stats.gov.cn/.

${ }^{47}$ See, for example, Cummins et al. (2003); Erhemjamts and Leverty (2007).
} 


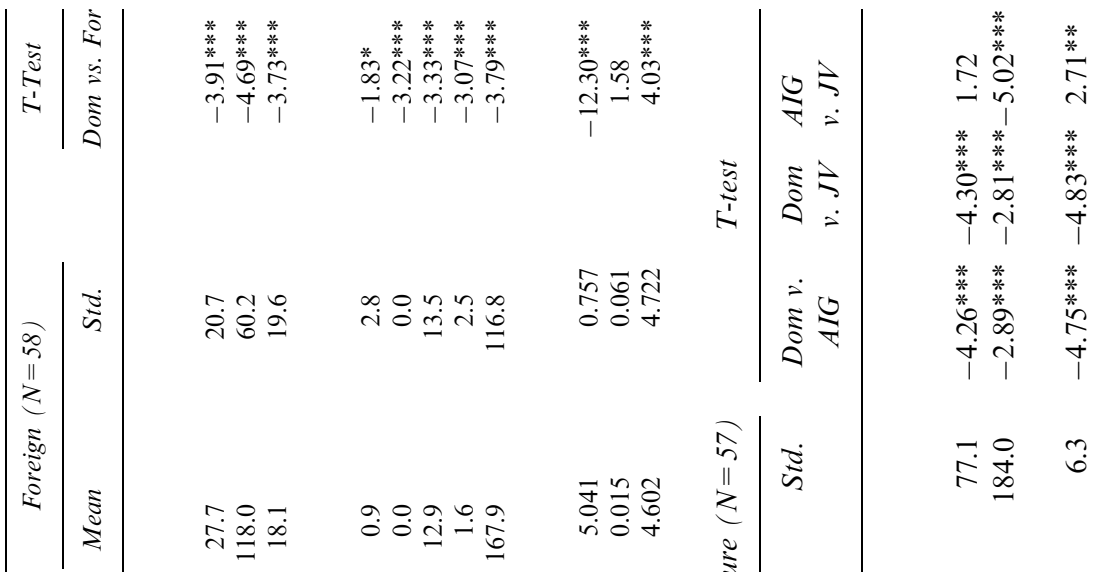

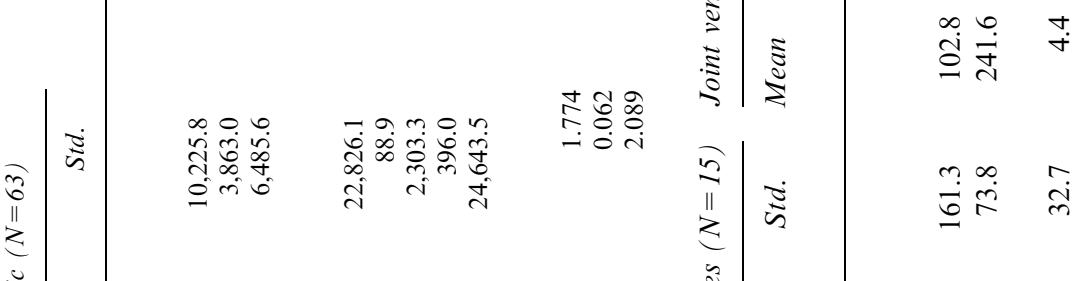

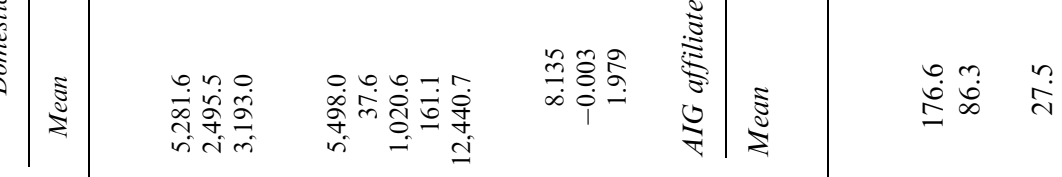

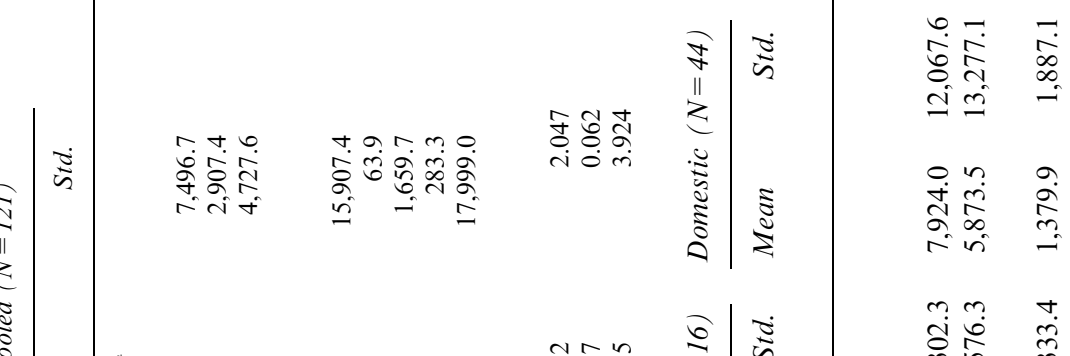

$$
\begin{aligned}
& \text { 党 }
\end{aligned}
$$

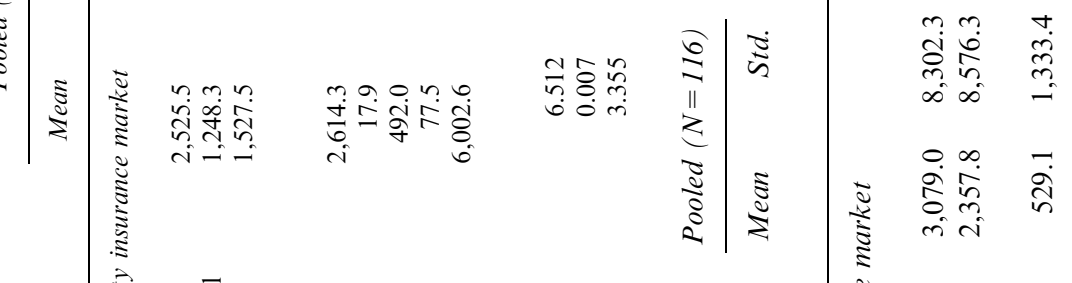

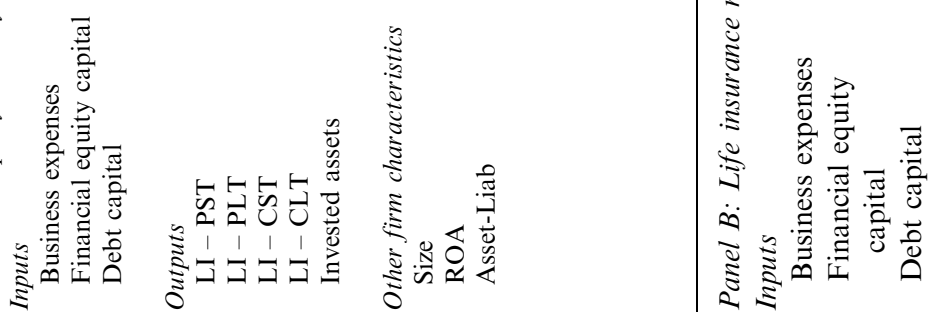




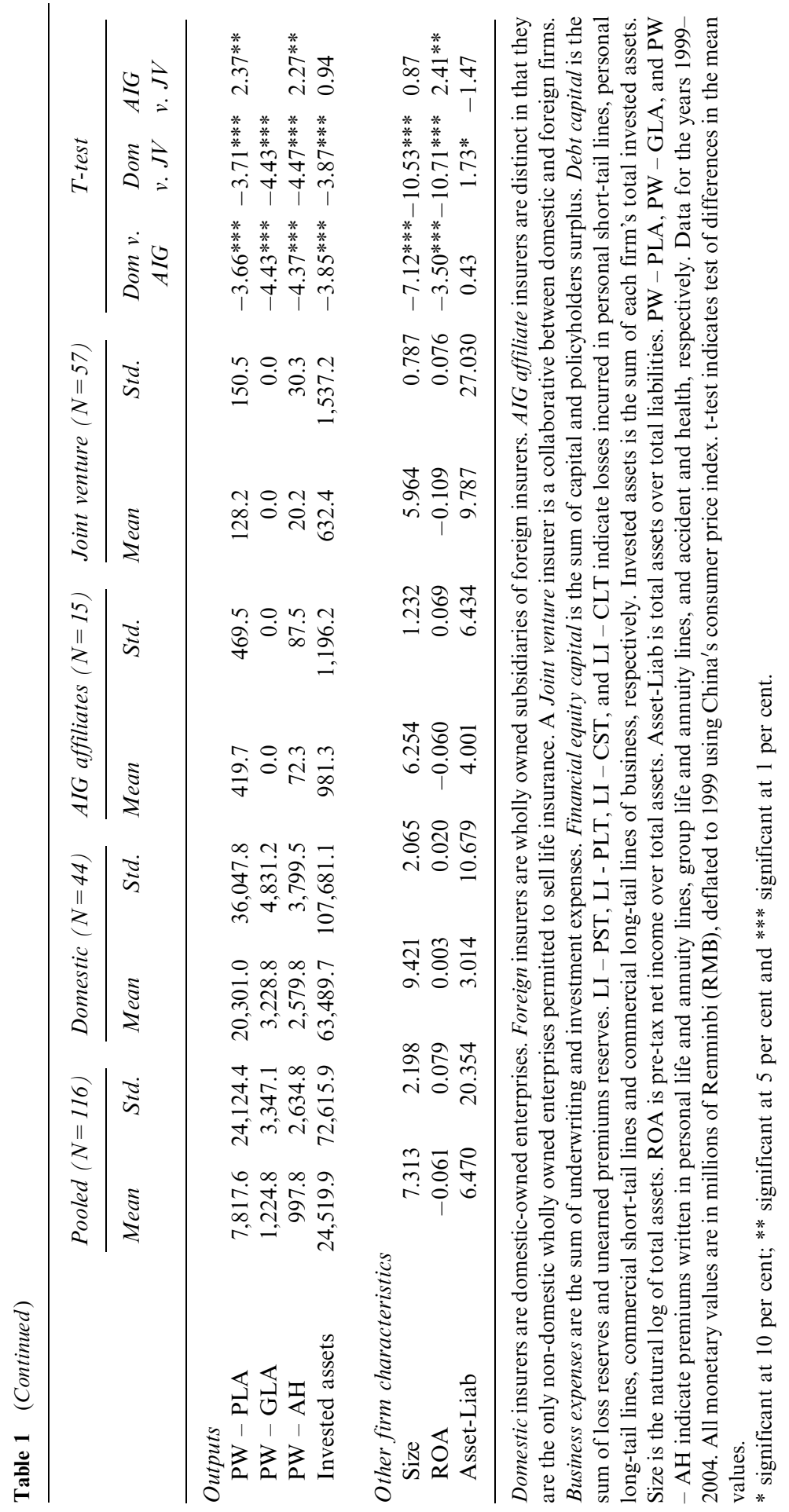




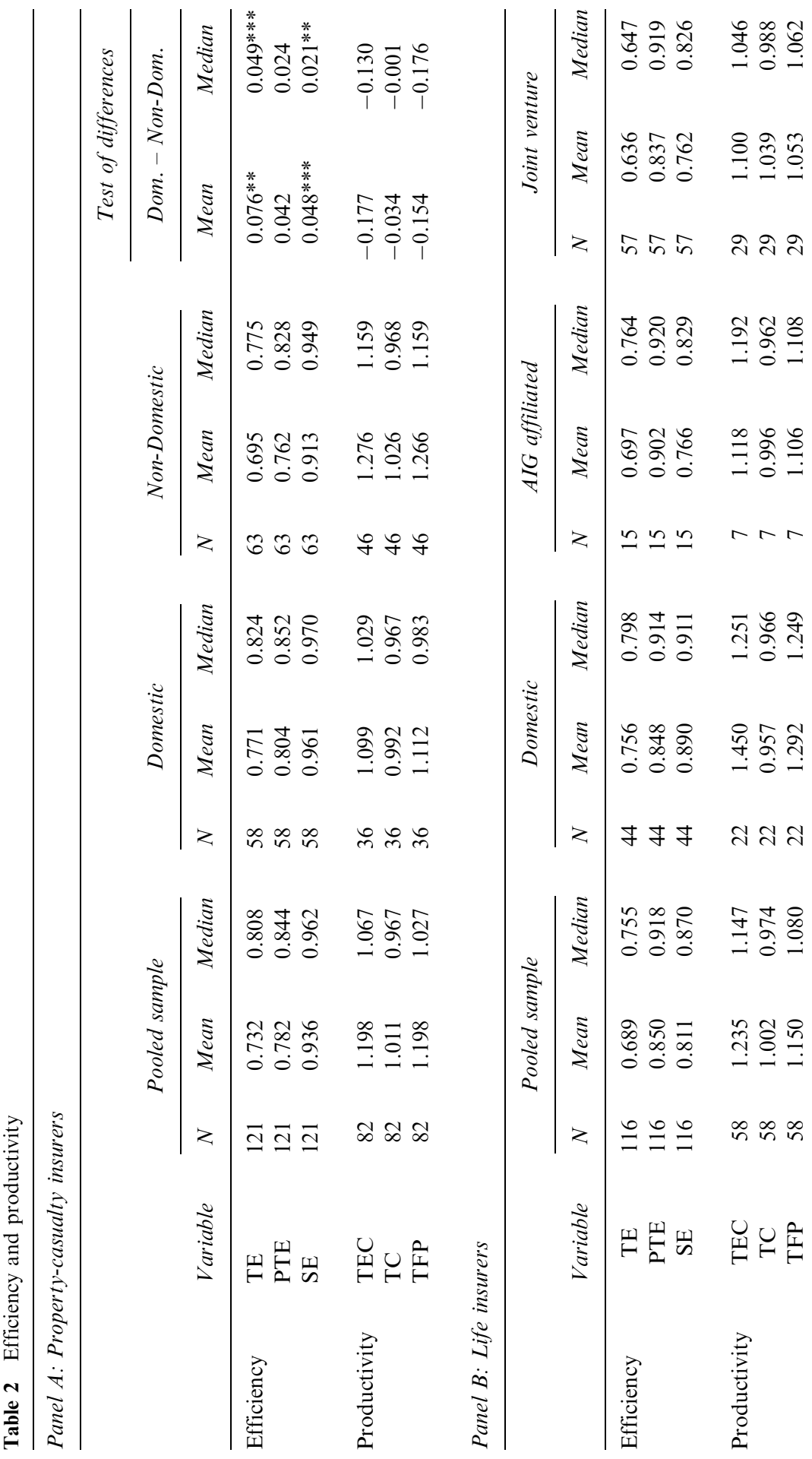




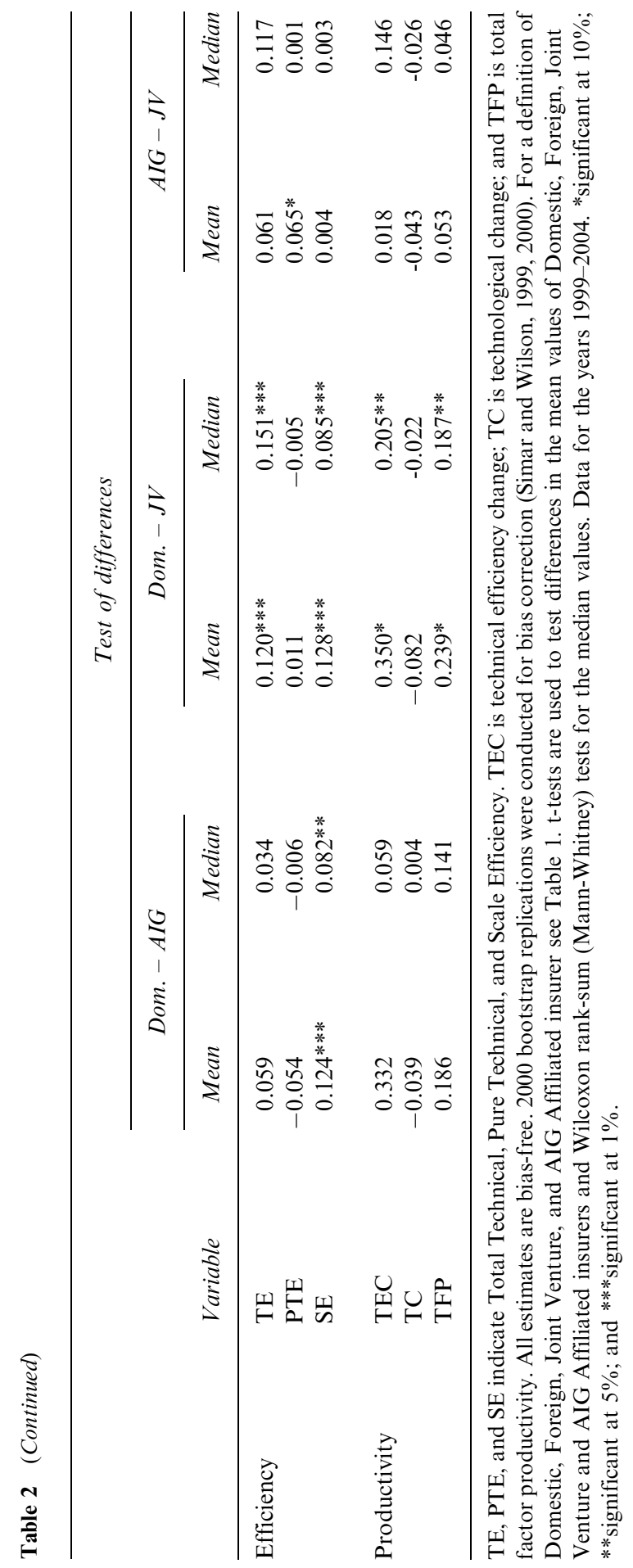


the average firm could reduce its input usage by 21.8 per cent. Average scale efficiency (SE) is 0.936. To also present an indication of the overall market efficiency, we calculate weighted average efficiencies using total assets as weights. The weighted average technical efficiency is 0.713 in 1999 and 0.732 in 2004. Thus both average and weighted average efficiencies trended upward over the sample period, which supports the hypothesis that efficiency increased over our sample period as China reduced its restrictions on foreign insurers.

The technical efficiency of domestic P\&C insurers (0.771) is significantly greater than that of non-domestic P\&C insurers (0.695). The efficiency difference between domestic and non-domestic P\&C insurers is 0.190 in 1999, but only 0.027 in 2004 . Thus, the divergence in efficiency between domestic and non-domestic insurers falls over the sample period.

Over the sample period, the average life insurer has TE, PTE and SE of 0.689, 0.850 and 0.811 , respectively. The weighted average is $0.711,0.854$ and 0.831 . Unlike the $\mathrm{P} \& \mathrm{C}$ industry, both average and weighted average efficiencies trended downward over the sample period. The results reveal that domestic life insurers are more TE and SE than the JV insurers and more SE than AIG affiliates. In turn, AIG affiliates are more PTE than JV firms. A univariate setting, however, may be misleading since factors outside the control of firms are not properly accounted.

Economics of scale (increasing returns to scale) are present if average costs per unit of output fall as the volume of output rises. The typical source of scale economies is the distribution of the firm's fixed costs (such as computer systems, managerial expertise and financial capital) over a larger volume of output. Since the Chinese government imposes high capital requirements and restricts the lines of business and geographical regions that non-domestic insurers can participate in, additional investigation into insurer's economies of scale is warranted. Over the sample period, approximately 50 per cent of foreign P\&C insurers, 47 per cent of AIG affiliated life insurers and 61 per cent of JV life insurers are operating with IRS, while only 29 and 18 per cent of domestic $\mathrm{P} \& \mathrm{C}$ and life insurers are operating on this part of the production function (results are not shown - differences are significant at the 5 per cent level). Thus, increasing production would reduce unit costs for a majority of nondomestic insurers but for only a small number of domestic insurers. On the other hand, only 9 per cent of non-domestic P\&C firms and 5.3 per cent of JV life firms were operating with DRS, while 20 per cent of domestic life and 14 per cent of domestic $\mathrm{P} \& \mathrm{C}$ insurers are operating at a point at which reducing production would result in a decline in unit costs (differences between domestic and non-domestic insurers are significant at the 10 per cent level). No AIG affiliate demonstrates DRS. Overall the implication of these results is that China's policies may create incentives for domestic firms to be too large and non-domestic firms to be too small.

Table 2 also reports bias-free Malmquist estimates. Malmquist indices compare performance relative to the production frontier for two different years; therefore, the identical sample of firms must be available in both comparison years. We use all firms present in each adjacent 2-year comparison period. Total factor productivity (TFP) represents average annual productivity growth in a period. It can be viewed as an indirect measure of the social welfare gains in the industry. An important conclusion from Table 2 is that the Chinese insurance market experienced considerable 
productivity growth over the sample period, 1999-2004. For the P\&C and life insurance industries, total factor productivity (TFP) grew at 19.8 and 15.0 per cent per year, respectively. ${ }^{48}$ These per year TFP results imply a TFP growth over the sample period of 118.8 per cent for the P\&C industry and 90.0 per cent for the life insurance industry.

The growth in productivity is mainly attributable to improvements in technical efficiency (better use of inputs - TEC) rather than technological progress (increases in the production frontier - TC). Average technical efficiency change (TEC) is 19.8 and 23.5 per cent for the P\&C and life industries. Thus, firms were "catching up" to the frontier, providing additional evidence that efficiency increased over the sample period. Mean technological change (TC), the outward shift of the production frontier, is only 1.1 and 0.2 per cent, respectively. There is no significant difference in the TFP between domestic and foreign P\&C insurers over the sample period, while domestic life insurers have significantly greater TEC and TFP than JV insurers.

\section{Determinants of efficiency and productivity}

The empirical analysis of the determinants of efficiency is conducted on a pooled sample of 237 life and P\&C insurers, and the analysis of the determinants of productivity is performed on a pooled sample of 140 insurers. Three dependent variables for efficiency - technical efficiency (TE), pure technical efficiency (PTE) and scale efficiency (SE) - and three dependent variables for productivity - technical efficiency change (TEC), technological change (TC) and total factor productivity (TFP) - are used. Even though we estimate separate frontiers for the P\&C and life samples to obtain measures of efficiency and productivity, we combine the two samples here to determine how reducing restrictions on foreign firms impacts the insurance industry as a whole. It is quite possible, however, that the P\&C and life business could differ from each other structurally and a pooled regression may not be able to capture the difference. To account for this, we also run separate regressions (not tabulated) for the $\mathrm{P} \& \mathrm{C}$ and life samples separately. The results are qualitatively identical to the pooled sample. For the sake of brevity we only report the results of the pooled sample.

Two explanatory variables serve as our main variables of interest. First, to assess the impact of relaxing foreign entry restrictions we use a WTO indicator variable (WTO). The variable is set equal to one for the years following China's accession to the WTO, 2002 to 2004, and zero otherwise. Second, to investigate the influence of the product and geographical restrictions on non-domestic insurers we use the per cent of total premium not open to non-domestic insurers (Restricted). Over the sample period, roughly 79.30 per cent of the total premiums written in China were in product lines and geographical regions that were off-limits to non-domestic insurers. Other variables are also included to control for firm and market characteristics that may be related to efficiency (productivity). ${ }^{49}$

${ }^{48}$ TFP grew at 8.7 and 7.2 per cent for the P\&C and life insurance industries based on the geometric mean.
${ }^{49}$ The log of total assets ( Size) controls for firm size. We also include size squared (Size $e^{2}$. The ratio of total 
The regression results appear in Table $3 .^{50}$ The efficiency results indicate that insurer performance does not significantly rise with China's accession to the WTO. One possible explanation is that efficiency steadily improves over the sample period. ${ }^{51}$ Moreover, the efficiency regressions only track trends in annual average efficiency scores over time and therefore it is not possible to infer efficiency changes because the efficiency scores do not take into account shifts in the frontier. The results do indicate, however, that restrictions imposed on the geographic and product scope of foreign insurers, significantly retard efficiency. The elasticity of Restricted with respect to technical efficiency is -0.32 , indicating that a 10 per cent reduction in the markets open to non-domestic insurers results in an approximate 3.2 per cent drop in technical efficiency. The major source of the technical efficiency loss due to regulatory restrictions arises from lower pure technical efficiency, but the restrictions also lower scale efficiency.

Ostensibly, one of the main purposes of relaxing foreign entry regulations is to allow domestic firms to learn from "more sophisticated" international firms. Similar to other financial institution studies ${ }^{52}$ and in contrast to China's concern that domestic insurers would be at a competitive disadvantage relative to "more sophisticated" international insurers, the results reveal that the average efficiency of domestic insurers improves after WTO accession. Specifically, the interaction variable, Domestic*WTO, is positive and significant for technical and scale efficiency. These results suggest that domestic insurers are not harmed, but rather benefit from the entry of foreign competitors. The mechanism for these benefits could be that the foreign insurers introduce new services, technology and skills that domestic companies copy, increase the quality of human capital in the industry, or simply that the presence of foreign competitors may motivate domestic firms to cut costs. This finding is also consistent with the home field advantage hypothesis ${ }^{53}$ which suggests that the advantage of domestic institutions' may be sourced in costs borne by foreign institutions such as monitoring from a distance, staff turnover in overseas postings, diseconomies of operation in the retail sector, and barriers to entry such as language, culture, market structure and regulations.

assets to total liabilities (Asset-Liab) is incorporated to determine the relationship of leverage on firm efficiency. To control for firm profitability, return on assets $(R O A)$, pre-tax net income over total assets, is used. Organisational characteristics are controlled by using indicator variables for life insurers (Life Insurer) and domestic insurers (Domestic). We also include insurance premium growth (Premium Growth) to control for the economic development of China's insurance market. As a robustness check, we also include GDP growth in place of Premium Growth. The results are quite similar.

${ }^{50}$ All continuous variables in the productivity regressions are firm averages over each adjacent 2-year period in which productivity is estimated. As a robustness check, we also perform the productivity regressions using the change in each independent variable for each adjacent 2-year period. The results are qualitatively similar.

${ }^{51}$ To investigate this possibility, we track how insurer efficiency evolves through time relative to efficiency in 1999. Specifically, we regress TE on a set of time dummies and following Baltagi and Griffen (1988) construct an index of efficiency change. The performance index suggests that insurer performance improves at an average annual rate of 10.4 per cent over the sample period. This improvement is fairly stable over the sample period as the standard deviation of the annual efficiency change is less than 9 per cent.

${ }^{52}$ For example, DeYoung and Nolle (1996); Mahajan et al. (1996); Berger et al. (2000b).

${ }^{53}$ Berger et al. (2000b). 
Table 3 Determinants of efficiency and productivity

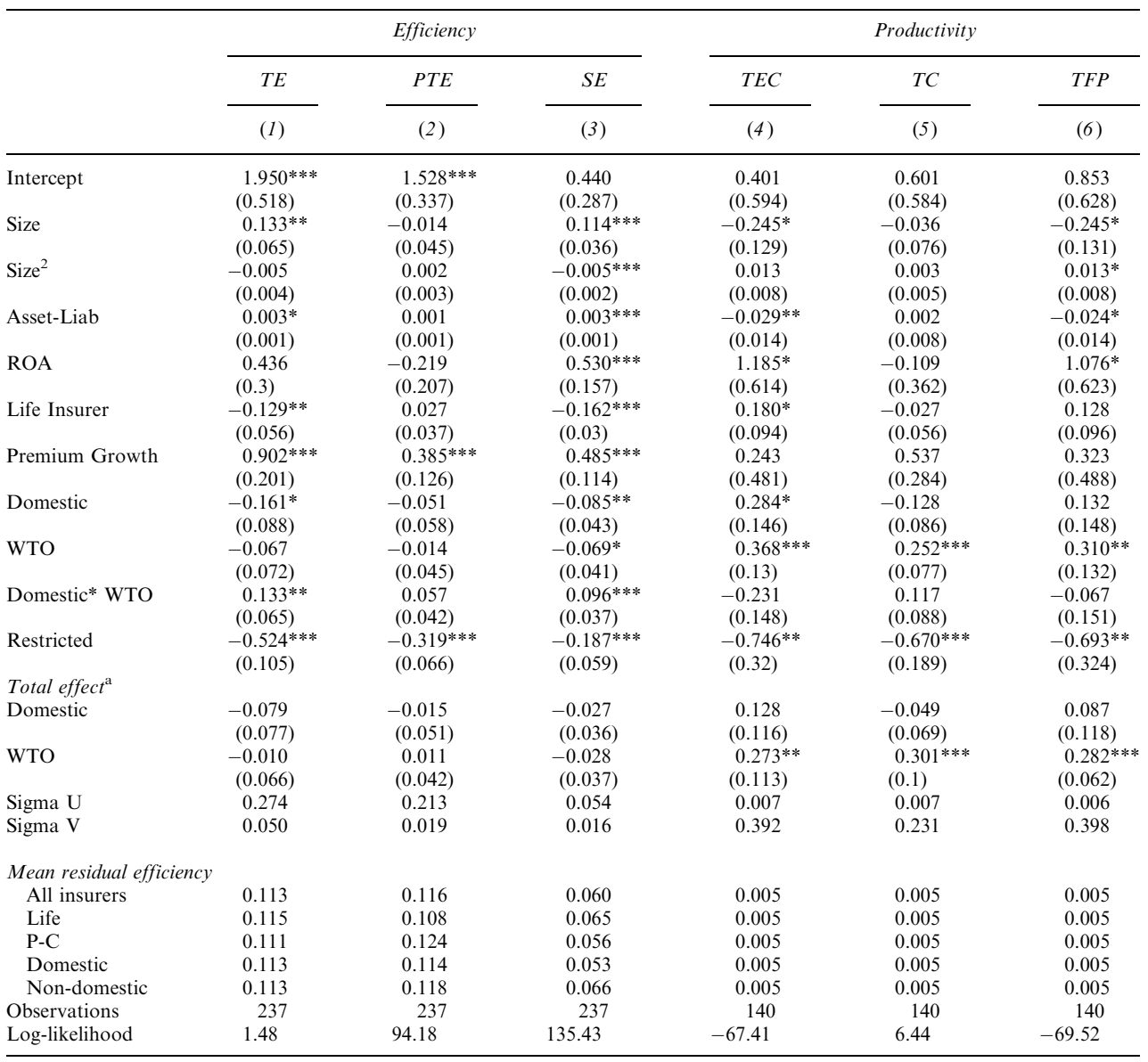

Note: All regressions are estimated using a Stochastic Frontier Approach (SFA) model. The dependent variable is $\log$ efficiency or log productivity. TE is Total Technical Efficiency; PTE is Pure Technical Efficiency and SE is Scale Efficiency. TEC is Technical Efficiency Change; TC is Technological Change and TFP is Total Factor Productivity. The efficiency and productivity estimates are bias-free; 2000 bootstrap replications were conducted for bias correction (Simar and Wilson, 1999, 2000). Size is the natural log of total assets. Asset-Liab is total assets over total liabilities. ROA is pre-tax net income over total assets. Life Insurer is an indicator variable set equal to one for life insurers, and zero otherwise. WTO is an indicator variable set equal to one for each year following China's official membership in the WTO, and zero otherwise. Premium Growth is the yearly percentage increase in total insurance premiums in China. Domestic is an indicator variable set equal to one for Chinese insurers. Restricted is the per cent of total premiums not open to non-domestic insurers. Sigma $\mathrm{U}$ is the symmetric white noise error term. Sigma V is the one-sided error term, that is, the unexplained inefficiency term. Mean Residual Efficiency is the estimated conditional mean of Sigma V given Sigma U. It is a measure of the random component of the estimated biasfree DEA efficiency scores that cannot be explained by the included explanatory variables. Data for the years 1999-2004. Standard errors are reported in parentheses below the estimated coefficients. * significant at 10 per cent; ** significant at 5 per cent and *** significant at 1 per cent.

${ }^{a}$ The Total Effect is the composite linear combination evaluated at the mean. For example, the total effect of WTO is: $\beta_{\text {WTO }}+\left(\beta_{\text {Domestic } \times \text { WTO }}\right)\left(\mu_{\text {Domestic }}\right)$. 
Looking at the productivity results, we observe that accession to the WTO positively influences productivity. In particular, China's accession to WTO yielded an outward shift in the efficient production frontier and induced firms to improve their efficiency relative to the frontier. The improvement in technological change and technical efficiency change translates into a significant advance in TFP. Restricted is negative and significant for all three dependent variables, indicating that China's product and geographical restrictions on non-domestic insurers impede technical efficiency change and technology change. Domestic insurers also realise greater technical efficiency change relative to non-domestic insurers. Overall, these findings are consistent with the hypothesis that reducing restrictions on foreign insurers improves productivity.

The magnitude of the random unexplained component of the variation in measured efficiency and productivity is also summarised in Table 3 . The estimated conditional mean of $v$ given $\varepsilon$, residual efficiency, measures the random component of efficiency (productivity) that cannot be explained by the independent variables included in the model. Our estimates show that on average 11.3, 11.6 and 6.0 per cent of the variation in TE, PTE and SE remains unexplained, respectively. The mean residual efficiency of non-domestic insurers is relatively greater than that for domestic firms (for PTE and $\mathrm{SE}$ ), suggesting that the explanatory variables do not explain as much of the variation in the efficiency of non-domestic insurers compared to domestic insurers. This discrepancy potentially reveals the inability of our explanatory variables to capture the full extent of China's uneven regulatory treatment of non-domestic firms. On average roughly 0.5 per cent of the variation in TEC, TC and TFP remains unexplained. Overall, the small estimated random efficiency and productivity effects imply that the SFA regression model is well specified and offers an accurate description of the determinants of measured efficiency and productivity variation.

\section{Sources of efficiency}

We also examine whether non-domestic insurers directly influence firm performance. DEA uses a standard linear programming technique to pinpoint peer groups of firms for each firm being evaluated. We take advantage of this artefact to create a measure of a firm's influence on the other firms in the industry - the number of times a firm is characterised as a member of the best-practice reference set of firms. If a firm is fully efficient (efficiency=1), then it has only one peer group firm, itself. On the other hand, if the firm is inefficient (efficiency $<1$ ), then that firm's efficient frontier is formed by a convex combination of other firms in the industry. We record the number of times a firm is a member of the set of "best-practice" constant returns to scale (CRS) frontier. ${ }^{54} \mathrm{~A}$ firm that more frequently comprises the reference set of firms arguably has more influence on the industry.

We use Negative Binomial count model econometric techniques to analyse the characteristics of the reference set of "best-practice" firms. ${ }^{55}$ For the P\&C sample, the

\footnotetext{
${ }^{54}$ The frontier count is based on the original DEA efficiency estimates.

${ }^{55}$ The Poisson regression model is the most widely used technique to study count data. A shortcoming of
} 
mean (median) number of times a firm is represented in the "best-practice" frontier is $1.95(0)$. In the life sample, the average (median) is $1.94(0)$. The independent variables are largely the same set of variables used in the previous models. However, two modifications are made. First, all explanatory variables are segmented into two time periods, before China's accession to the WTO and after it. The variables can be viewed as being interacted with a Pre-WTO (Post-WTO) indicator variable set equal to one for the years prior to (after) accession and zero otherwise. The segmentation allows us to determine whether there is a structural shift in the firm characteristics that influence the industry due to the rules set forth by WTO accession. Second, we classify non-domestic insurers into JV and foreign insurer categories. Foreign insurers are defined as foreign $\mathrm{P} \& \mathrm{C}$ insurers and AIG-affiliated life insurers. The intent of this categorisation is to determine whether influence differs depending on non-domestic ownership structure.

The regression results are shown in Table 4. Prior to China's official accession to the WTO, both JV and foreign firms have a positive effect on the market. These results provide some evidence that non-domestic insurers positively influence the Chinese insurance market. After accession, only foreign insurers positively influence the market. Prior to accession foreign parties are allowed a 51 per cent ownership stake in JV firms, while after WTO accession, foreign ownership in JVs is capped at 50 per cent. Thus, the divergence between the before and after WTO accession results for JV insurers may be a consequence of the involuntary mixed ownership structure of JV operations or which party controls the majority ownership interest.

The geographic and product restrictions placed on non-domestic insurers reduce a firm's ability to positively influence the Chinese insurance industry. The negative impact of China's restrictions on non-domestic insurers is greater in the period prior to WTO accession when the restrictions were more severe. On the whole, these results indicate that reducing restrictions on non-domestic insurers improves performance.

\section{Conclusion}

From 1999, when China began preparation for entrance into the WTO, to 2004, the end of our sample period, the Chinese insurance market experienced large productivity gains of 19.8 and 15.0 per cent in the $\mathrm{P} \& \mathrm{C}$ and life insurance industries. In general, we find strong support for the hypothesis that the entry of foreign firms improves efficiency. ${ }^{56}$ Our results reveal that the average efficiency of domestic insurers improves after WTO accession, suggesting, in contrast to the Chinese governments concerns, domestic insurers benefit by the entry of foreign competitors. Ostensibly, one of the main purposes of relaxing foreign entry regulations is to allow domestic firms to learn from "more sophisticated" international firms. We find that foreign insurers are more likely to be represented in the "best-practice" frontier, providing some evidence that foreign insurance companies are positively influencing performance in the Chinese market.

the Poisson model, however, is the assumed equality of the conditional mean and variance functions. We conduct a goodness-of-fit test of the Poisson model using the deviance statistic. The appropriateness of the Poisson model is rejected.

${ }^{56}$ Denizer (1999); Claessens et al. (2001); Barajas et al. (2000); Unite and Sullivan (2003). 
Table 4 Frontier count regressions

\begin{tabular}{|c|c|c|}
\hline & (1) & (2) \\
\hline Intercept & $\begin{array}{c}-9.628 * * * \\
(1.944)\end{array}$ & $\begin{array}{c}-9.411 * * * \\
(2.398)\end{array}$ \\
\hline \multicolumn{3}{|c|}{ Pre-WTO accession } \\
\hline Size & $\begin{array}{l}1.531 * * * \\
(0.454)\end{array}$ & $\begin{array}{l}2.215^{* * * *} \\
(0.513)\end{array}$ \\
\hline Size $^{2}$ & $\begin{array}{c}-0.074 * * * \\
(0.026)\end{array}$ & $\begin{array}{l}-0.112 * * * \\
(0.029)\end{array}$ \\
\hline Asset-Liab & $\begin{array}{l}0.109^{* *} \\
(0.044)\end{array}$ & $\begin{array}{l}0.137^{* * * *} \\
(0.05)\end{array}$ \\
\hline ROA & $\begin{array}{c}0.148 \\
(2.764)\end{array}$ & $\begin{array}{c}-0.588 \\
(2.915)\end{array}$ \\
\hline Life & $\begin{array}{c}-0.472 \\
(0.308)\end{array}$ & $\begin{array}{c}-0.585^{* *} \\
(0.298)\end{array}$ \\
\hline Joint Venture & $\begin{array}{l}1.199 * * \\
(0.563)\end{array}$ & $\begin{array}{l}1.398 * * \\
(0.579)\end{array}$ \\
\hline Foreign & $\begin{array}{c}0.749^{*} \\
(0.434)\end{array}$ & $\begin{array}{l}1.039 * * \\
(0.453)\end{array}$ \\
\hline Restricted & & $\begin{array}{c}-3.672 * \\
(2.19)\end{array}$ \\
\hline \multicolumn{3}{|c|}{ Post-WTO accession } \\
\hline Size & $\begin{array}{l}1.300^{* * *} * \\
(0.421)\end{array}$ & $\begin{array}{l}1.190^{* *} \\
(0.511)\end{array}$ \\
\hline $\mathrm{Size}^{2}$ & $\begin{array}{c}-0.053^{* *} \\
(0.023)\end{array}$ & $\begin{array}{c}-0.047 * \\
(0.027)\end{array}$ \\
\hline Asset-Liab & $\begin{array}{c}0.008 \\
(0.012)\end{array}$ & $\begin{array}{c}0.007 \\
(0.012)\end{array}$ \\
\hline ROA & $\begin{array}{c}0.548 \\
(2.454)\end{array}$ & $\begin{array}{l}1.100 \\
(2.577)\end{array}$ \\
\hline Life & $\begin{array}{c}0.219 \\
(0.413)\end{array}$ & $\begin{array}{c}0.177 \\
(0.401)\end{array}$ \\
\hline Joint Venture & $\begin{array}{c}-0.152 \\
(0.537)\end{array}$ & $\begin{array}{c}0.003 \\
(0.567)\end{array}$ \\
\hline Foreign & $\begin{array}{l}1.633^{* * * *} \\
(0.51)\end{array}$ & $\begin{array}{l}1.580^{* * * *} \\
(0.574)\end{array}$ \\
\hline Restricted & & $\begin{array}{c}-0.525^{*} \\
(0.29)\end{array}$ \\
\hline Pseudo $R^{2}$ & 0.046 & 0.050 \\
\hline Log likelihood & -403.2 & -401.7 \\
\hline Observations & 237 & 237 \\
\hline
\end{tabular}

Note: The dependent variable is the number of times a particular firm is represented in the efficient constant returns to scale frontier. The dependent variable serves as a measure of a firm's influence on the other firms in the industry. The relationship of the explanatory variables is measured before and after China's accession to the WTO on 11 December 2001. Size is the natural log of total assets. Asset-Liab is total assets over total liabilities. ROA is pre-tax net income over total assets. Life is an indicator variable for life insurers. Joint Venture is a dummy variable for joint venture life insurers. Foreign is an indicator variable set equal to one for foreign P-C insurers and AIG-affiliated life insurers, that is, for all non-domestic enterprises that are permitted greater than 50 per cent ownership. Restricted is the per cent of total premiums not open to nondomestic insurers. Data for the years 1999-2004. All regressions are estimated using a Negative Binomial Count model. Robust standard errors are reported in parentheses below the estimated coefficients.

* significant at 10 per cent; ** significant at 5 per cent and *** significant at 1 per cent. 
We also find that regulatory restrictions impede insurer efficiency and productivity. ${ }^{57}$ Specifically, restrictions imposed on the geographic and product scope of foreign insurers retard efficiency and productivity improvements. Moreover, we discover that the greater loosening of regulatory restrictions in the P\&C industry, relative to the life insurance industry, is more effective in promoting efficiency. Both findings lend support to the argument that restrictive regulatory environments impede the welfare gains from the entry of foreign insurers. Overall, these results suggest that further efficiency improvements may be made by easing geographic and product regulatory restrictions.

A limitation of our study is the condensed time-frame under analysis, 1999 to 2004. China began taking steps to liberalise their insurance market in late 1998 in preparation for accession into the WTO. Thus, our data set does not capture the preliberalisation period. We also only capture the short-term impact of liberalisation since our sample period ends in 2004. Overall, the focus of this study is on the transition phase of China's liberalisation programme. We encourage follow-up research on the long-term effect of liberalisation in China.

\section{References}

Baltagi, B.H. and Griffin, J.M. (1988) 'A generalized error component model with heteroscedastic disturbances', International Economic Revies 29: 745-753.

Banker, R. (1993) 'Maximum likelihood, consistency, and data envelopment analysis: A statistical foundation', Management Science 39(10): 1265-1273.

Barajas, A., Salazar, N. and Steiner, R. (2000) 'Foreign investment in Colombia's financial sector', in S. Claessens and M. Jansen (eds) The Internationalization of Financial Services: Issues and Lessons for Developing Countries, Dordrecht: Kluwer Academic Press.

Barros, C.P., Barroso, N. and Borges, M.R. (2005) 'Evaluating the efficiency and productivity of insurance companies with a Malmquist index: A case study for Portugal', The Geneva Papers on Risk and InsuranceIssues and Practice 30(2): 244-267.

Berger, A.N., Cummins, J.D., Weiss, M.A. and Zi, H. (2000a) 'Conglomeration versus strategic focus: Evidence from the insurance industry', Journal of Financial Intermediation 9(4): 323-362.

Berger, A.N., DeYoung, R., Genay, H. and Udell, G. (2000b) 'Globalisation of financial institutions: Evidence from cross-border banking performance', Brookings-Wharton Papers on Financial Service 3: $23-120$.

Berger, A.N. and Hannan, T.H. (1998) 'The efficiency cost of market power in the banking industry: A test of the "Quiet Life" and related hypotheses', The Review of Economics and Statistics 80(3): 454-465.

Berger, A.N. and Humphrey, D.B. (1992) 'Measurement and efficiency issues in commercial banking', in Z. Griliches (ed) Output Measurement in the Services Sector, Chicago: University of Chicago Press.

Berger, A.N. and Humphrey, D.B. (1997) 'Efficiency of financial institutions: International survey and directions for future research', European Journal of Operational Research 98(2): 175-212.

Berger, A.N., Hasan, I. and Zhou, M. (2009) 'Bank ownership and efficiency in China: What will happen in the worl's largest nation', Journal of Banking and Finance 33(1): 113-130.

Bhattacharyya, A., Lovell, C.A.K. and Sahay, P. (1997) 'The impact of liberalization on the productive efficiency of Indian commercial banks', European Journal of Operational Research 21(2): 332-345.

Bonin, J.P., Hasan, I. and Wachtel, P. (2005) 'Bank performance, efficiency and ownership in transition countries', Journal of Banking and Finance 29(1): 31-53.

Charnes, A., Cooper, W.W., Lewin, A. and Seiford, L.M. (eds) (1994) Data Envelopment Analysis: Theory, Methodology, and Applications, Boston, MA: Kluwer Academic Publishers.

Chen, B., Powers, M.R. and Qiu, J. (2007) 'Development of the chinese life insurance industry: An efficiency analysis', The Capco Institute: Journal of Financial Transformation 22: 123-130.

\footnotetext{
${ }^{57}$ Jayaratne and Strahan (1998).
} 
Denizer, C. (1999) 'Foreign entry in Turkey's banking sector, 1980-97'. World Bank Policy Research Working Paper No. 2462.

Cho, K.R. (1990) 'Foreign banking presence and banking market concentration: The case of Indonesia', The Journal of Development Studies 27(1): 98-110.

Claessens, S., Demirguc-Kunt, A. and Huizinga, H. (2001) 'How does foreign entry affect the domestic banking system', Journal of Banking and Finance 25(5): 891-911.

Cummins, J.D. and Rubio-Misas, M. (2006) 'Deregulation, consolidation, and efficiency: Evidence from the Spanish insurance industry', Journal of Money, Credit, and Banking 38: 323-355.

Cummins, J.D., Rubio-Misas, M. and Zi, H. (2004) 'The effect of organizational structure on efficiency: Evidence from the Spanish insurance industry', Journal of Banking and Finance 28: 3113-3150.

Cummins, J.D. and Weiss, M.A. (2001) 'Analysing firm performance in the insurance industry using frontier efficiency and productivity models', in G. Dionne (ed) Handbook of Insurance, Boston, MA: Kluwer Academic Publishers.

Cummins, J.D., Weiss, M.A. and Zi, H. (2003) Economies of scope in financial services: A DEA bootstrapping analysis of the US insurance industry, University of Temple Working Paper.

D'Arcy, S.P. and Xia, H. (2003) 'Insurance and China's entry into the WTO', Risk Management and Insurance Review 6(1): 7-25.

Demirguc-Kunt, A., Laeven, L. and Levine, R. (2002) 'Regulations, market structure, institutions, and the cost of financial intermediation', Journal of Money, Credit, and Banking 36(3): 593-622.

China Insurance Regulatory Commission (1993-2004) 'Yearbook of China's insurance', Beijing: Yearbook of China's Insurance Publisher.

DeYoung, R. and Nolle, D. (1996) 'Foreign-owned banks in the United States: Earning market share or buying it', Journal of Money, Credit, and Banking 28(4): 622-636.

Erhemjamts, O. and Leverty, J.T. (2007) The demise of the mutual organizational form: An investigation of the life insurance industry, University of Iowa Working Paper.

Ennsfellner, K.D., Lewis, D. and Anderson, R.I. (2004) 'Production efficiency in the Austrian insurance industry: A Bayesian examination', Journal of Risk and Insurance 71(1): 134-159.

Gardner, L. and Grace, M.F. (1993) 'X-Efficiency in the US Life insurance industry', Journal of Banking and Finance 17(2-3): 497-510.

Grosskopf, S. (1993) 'Efficiency and productivity', in H.O. Fried, C.A.K. Lovell and S.S. Schmidt (eds) The Measurement of Productive Efficiency, New York: Oxford University Press.

Guan, H. (2003) 'Impact of WTO accession on benefit sharing in China's insurance market', China Insurance Studies 177: 19-21.

Jayaratne, J. and Strahan, P.E. (1998) 'Entry restrictions, industry evolution, and dynamic efficiency: Evidence from commercial banking', Journal of Law and Economics 41(1): 239-273.

Ji, C. and Thomas, S. (2001) The Role of Foreign Insurance Companies in China's Emerging Insurance Industry: An FDI Case Study, paper presented at the Conference on Financial Sector Reform in China, September, China.

Kroszner, R. (1998) 'On the political economy of banking and financial regulatory reform in emerging markets', Research in Financial Services 10: 33-51.

Lensink, R. and Hermes, N. (2004) 'The short-term effects of foreign bank entry on domestic bank behavior: Does economic development matter?' Journal of Banking and Finance 28(3): 553-568.

Leverty, J.T. and Grace, M.F. (2007) 'Issues in Measuring the Efficiency of Property-Liability Insurers', ssrn.com/abstract $=899197$.

Levine, R. (1996) 'Foreign banks, financial development and economic growth', in C.E. Barfield (ed) International Financial Markets: Harmonization Versus Competition, Washington DC: AEI Press.

Mahajan, A., Rangan, N. and Zardkoohi, A. (1996) 'Cost structures in multinational and domestic banking', Journal of Banking and Finance 20(2): 283-306.

National Bureau of Statistics of China. (1995-2002) 'Statistics Communiqué of National Economy and Social Development', www.stats.gov.cn.

$\mathrm{Ng}$, E. and Whalley, J. (2004) Geographical extension of free trade zones as trade liberalization: A numerical simulation approach, CESifo Working Paper No. 1147.

Rose, N. (2006) Is China Living Up To Its WTO Insurance Commitments?, Norton Rose Company Report. 
Phillips, R.D., Cummins, J.D. and Allen, F. (1998) 'Financial pricing of insurance in the multiple-line insurance company', Journal of Risk and Insurance 65(4): 597-636.

Simar, L. and Wilson, P.W. (1998) 'Sensitivity analysis of efficiency scores: How to bootstrap in nonparametric frontier models', Management Science 44(1): 49-61.

Simar, L. and Wilson, P.W. (1999) 'Estimating and bootstrapping malmquist indices', European Journal of Operational Research 115(3): 459-471.

Simar, L. and Wilson, P.W. (2000) 'A general methodology for bootstrapping in nonparametric frontier models', Journal of Applied Statistics 27(6): 779-802.

Shen, Y. (2000) 'China's insurance market: Opportunity, competition and market trends', The Geneva Papers on Risk and Insurance - Issues and Practice 25(3): 335-355.

Sun, Q. (2003) 'The impact of WTO accession on China's insurance industry', Risk Management and Insurance Review 6(1): 27-35.

Thomas, J.E. (2002) 'The role and powers of the Chinese insurance regulatory commission in the administration of insurance law in China', The Geneva Papers on Risk and Insurance-Issues and Practice 27(3): 413-434.

Unite, A.A. and Sullivan, M.J. (2003) 'The impact of liberalization of foreign bank entry on the philippine domestic banking market', Journal of Banking and Finance 27(12): 2323-2345.

Wang, X., Xu, D. and Wang, H. (2006 Research on the Chinese insurance market liberalization, Beijing Technology and Business University Working Paper.

Whalley, J. (2003) Liberalization in China's key service sectors following WTO accession: Some scenarios and issues of measurement, NBER Working Paper.

Wilson, P.W. (2007) FEAR: A package for frontier efficiency analysis with $R$, unpublished working paper, Department of Economics, Clemson University.

$\mathrm{Wu}, \mathrm{X}$. and Strange, R. (2000) 'The location of foreign insurance companies in China', International Business Review 9(3): 383-398.

$\mathrm{Xu}, \mathrm{C}$. and $\mathrm{Li}$, L. (2003) 'On the domestic insurance market and entrance of foreign insurers', China Insurance Studies 177: 16-18.

Yao, S., Zhongwei, H. and Feng, G. (2007) 'On technical efficiency of China's insurance industry after WTO accession', China Economic Review 18(1): 66-86.

Yearbook of China's Insurance (1996-2004) Yearbook of China's Insurance, Beijing: Yearbook of China's Insurance Publisher.

Yuan, H. (2002 'Joint-ventures do not move smoothly', China Insurance 176: 31.

Yuengert, A. (1993) 'The measurement of efficiency in life insurance: estimates of a mixed normal-gamma model', Journal of Banking and Finance 17(2-3): 483-496.

Zou, H. and Adams, M.B. (2006) 'The corporate purchase of property insurance: Chinese evidence', Journal of Financial Intermediation 15(2): 165-196.

\section{Appendix}

\section{Formal and informal requirements for foreign insurers}

The formal requirements include:

(1) The prospective foreign insurers must operate a representative office (where no business can be conducted) in China for a minimum of two years.

(2) The assets of the prospective foreign insurer parent company must exceed US\$5 billion in the year prior to application.

(3) The parent company of the prospective foreign insurance company must have at least 30 years of experience in insurance underwriting in its home jurisdiction.

(4) The home country of the applicant must have a sound financial regulatory and supervision system. 
(5) The parent company of the prospective foreign insurance company must have complied with the solvency and other general requirements of authorities in its home jurisdiction.

(6) The prospective foreign insurance company must have obtained the "consent for the application" from the relevant authorities in its home jurisdiction.

(7) The prospective foreign insurer must be willing to meet China's capitalisation requirements: minimum registered capital of Rmb 200 million (US\$24 million).

(8) A foreign funded insurance company (FFIC) must inject a further Rmb 20 million (US\$2.4 million) each time it establishes a branch office (the FFIC is exempt from this requirement when its capitalisation reaches Rmb 500 million (US\$60 million)).

(9) The prospective foreign insurer must comply with any other requirements of the CIRC.

Some of the informal requirements include:

(1) The prospective foreign insurance company must demonstrate a long-term commitment to China by providing professional training to the CIRC and other insurance employees, organising financial seminars, establishing educational institutes and sponsoring research.

(2) The quality of the political and economic relations between the government of the prospective foreign insurer and government of China.

(3) The historical relationships between the company and China.

(4) Chinese authorities also attempt to maintain a worldwide geographic balance when granting permits.

Sources: D'Arcy and Xia (2003), Ji and Thomas (2001), Thomas (2002), Norton Rose (2006), Sun (2003) and the CIRC website (the English version www.circ.gov.cn/ is under construction).

\section{About the Authors}

J. Tyler Leverty is an Assistant Professor of Finance and faculty member of the Vaughan Institute of Risk Management and Insurance at the University of Iowa. His research interests are the economics of insurance markets and public policy issues in insurance. He has received awards for his research including the State Farm Companies Doctoral Dissertation Award and the Casualty Actuarial Society Best Paper Award in 2005.

Yijia Lin is an Assistant Professor of Finance at the University of Nebraska, Lincoln. Her research interests are in insurance and risk management. Dr. Lin has published papers in the Journal of Risk and Insurance, the North American Actuarial Journal and the Insurance: Mathematics and Economics. She was the Harold D. Skipper Best Paper Award winner in 2006 and won the Ernst Meyer Prize for University Research Work by The Geneva Association in 2007.

Hao Zhou is an Assistant to the Representative of Allianz General Representative Office in China. He joined Allianz in 2002, after he graduated from Beijing Technology and Business University, majoring in Insurance. One of his main job responsibilities is to collect China's insurance market information and analyse the market development trends. 